\title{
Explosive volcanism as a cause for mass mortality of pteropods
}

\author{
Deborah Wall-Palmer a,*, Morgan T. Jones ${ }^{\mathrm{b}, 1}$, Malcolm B. Hart ${ }^{\mathrm{a}}$, Jodie K. Fisher ${ }^{\mathrm{a}}$, Christopher W. Smart ${ }^{\mathrm{a}}$, \\ Deborah J. Hembury ${ }^{\mathrm{b}}$, Martin R. Palmer ${ }^{\mathrm{b}}$, Gary R. Fones ${ }^{\mathrm{c}}$ \\ a School of Geography, Earth E Environmental Sciences, University of Plymouth, Drake Circus, Plymouth PL4 8AA, United Kingdom \\ b School of Ocean E Earth Sciences, National Oceanography Centre, University of Southampton, European Way, Southampton SO14 3ZH, United Kingdom \\ c School of Earth E Environmental Sciences, University of Portsmouth, Burnaby Building, Burnaby Road, Portsmouth PO1 3QL, United Kingdom
}

\section{A R T I C L E I N F O}

\section{Article history:}

Received 23 June 2010

Received in revised form 15 December 2010

Accepted 2 March 2011

Available online 13 March 2011

Communicated by G.J. de Lange

\section{Keywords:}

Pteropod

Soufrière Hills Volcano

Montserrat

Ocean acidification

Ash-leachates

Explosive volcanism

\begin{abstract}
A B S T R A C T
Recently, it has been proposed that anthropogenic $\mathrm{CO}_{2}$ emissions may affect marine ecosystems by causing ocean acidification. In particular, it is suggested that within acidified waters, calcifying organisms would be subject to malformation and enhanced dissolution. Here, we present evidence suggesting that this process occurs naturally where explosive volcanism deposits ash directly into ocean surface waters. Sediment cores from around the island of Montserrat, Lesser Antilles volcanic arc, contain distinct horizons of planktic fauna associated with recently deposited volcanic ash layers from the Soufrière Hills volcano. Within these layers are abundant thecosome pteropod shells that display evidence of partial dissolution and etching of their aragonitic shells, and appear to have suffered mass mortality during large eruptions from the volcano. Laboratory studies show that the acids bound to ash surfaces from the 2003 volcanic dome collapse event of the Soufrière Hills volcano could have caused the upper $5 \mathrm{~m}$ of the water column to become undersaturated with respect to aragonite. When combined with the large fluxes of acidic aerosols (principally as $\mathrm{SO}_{2}$ ) from the volcano during eruptions, it is proposed that volcanogenic ocean acidification by marine ash falls is a significant contributing factor to these observed mass mortality events. (c) 2011 Elsevier B.V. All rights reserved.
\end{abstract}

\section{Introduction}

During explosive volcanic eruptions, a mixture of tephra (airborne volcanic particulate matter) and gases are injected into the atmosphere and deposited at varying distances from a volcano. As the eruption cloud cools, metal salts and condensing volatile phases tend to nucleate on solid or liquid surfaces, leading to preferential adsorption of acids onto tephra surfaces and within local meteoric water (Rose, 1977; Oskarsson, 1980). Both processes lead to the accelerated deposition of acids proximal to a volcano. The acids and metal salts adhered to the particle surfaces, termed ash-leachates, are very soluble; dissolving within minutes of first contact with water (Duggen et al., 2007). Hence, the combined deposition of volcanic ash and acidified meteoric water can rapidly enrich surface waters proximal to a volcano with a wide suite of elements. The subsequent impact on the biological community depends heavily on the concentrations of elements released and the buffering capacity of the affected ecosystem (Frogner-Kockum et al., 2006). In marine surface waters, it has been suggested that increased concentrations of bio-limiting nutrients, such as N, P, Fe, and Mn, may instigate increases in primary productivity (Frogner et al., 2001; Duggen et al., 2007; Jones and Gislason, 2008). If correct, the subsequent amplification

\footnotetext{
* Corresponding author. Tel.: +44 1752584760.

E-mail address: deborah.wall-palmer@plymouth.ac.uk (D. Wall-Palmer).

1 Present Address: Institute of Earth Science, University of Iceland, Sturlugata 7, 101 Reykjavik, Iceland.
}

of $\mathrm{CO}_{2}$ uptake through the biological pump may offset, or even exceed, the out-gassing of volcanic $\mathrm{CO}_{2}$ (Sarmiento, 1993; Watson, 1997).

In addition to the potential nutrient supply from volcanic inputs there is, however, the potential for release of species that may inhibit biological growth, including elements that are fertilizers at lower concentrations (Brand et al., 1986; Sunda, 1988-1989; Bruland et al., 1991). For example, acids released during acid-leachate dissolution or by direct deposition, including $\mathrm{H}_{2} \mathrm{SO}_{4}, \mathrm{HCl}$ and $\mathrm{HF}$, lead to a significant decrease in the $\mathrm{pH}$ of the water (Frogner et al., 2001; Jones and Gislason, 2008). The extent to which aquatic environments are adversely impacted by tephra deposition varies greatly, with seawater being generally less susceptible due to its high buffering capacity (Frogner-Kockum et al., 2006). This property also limits the bioavailability of toxic ions such as $\mathrm{Cu}^{2+}$ and $\mathrm{Al}^{3+}$ (Moffett and Brand, 1996; Croot et al., 2000). The most sensitive biogeochemical cycle to surface seawater acidification is the carbonate system. In particular, aragonite, which is $50 \%$ more susceptible to dissolution than calcite (Mucci, 1983), is especially sensitive to changes in ocean chemistry. Hence a reduction of surface water $\mathrm{pH}$ values below $\sim 7.8$ (surface water undersaturated with respect to aragonite) may have deleterious consequences for aragonite precipitating organisms (Comeau et al., 2009).

Laboratory studies (Gattuso et al., 1998, Langdon et al., 2000; Riebesell et al., 2000; Feely et al., 2004; Orr et al., 2005; Comeau et al., 2009; Comeau et al., 2010a,b) and field investigations (Hall-Spencer et al., 2008) have shown that in general, calcification rates are reduced in acidified waters, and that calcareous organisms can show increased malformation and enhanced dissolution of calcareous structures. For 
example, gastropods (which form aragonitic shells) display partial dissolution of their shells around shallow hydrothermal vents that emit $\mathrm{CO}_{2}$ (Hall-Spencer et al., 2008). In recent controlled pH-temperature $\left(\mathrm{pH}_{\mathrm{T}}\right)$ experiments, the larvae of the Mediterranean pteropod Cavolinia inflexa maintained at $\mathrm{pH}_{\mathrm{T}} 7.82$ exhibited malformations and reduced shell growth when compared to those grown in control conditions at $\mathrm{pH}_{\mathrm{T}}$ 8.1. At $\mathrm{pH}_{\mathrm{T}}$ 7.51, the larvae failed to make shells, despite otherwise developing normally (Comeau et al., 2010b). However, experiments using Limacina helicina (a common high latitude thecosome pteropod) under controlled $\mathrm{pH}$-temperature conditions of 7.78 and $5{ }^{\circ} \mathrm{C}$, show that although calcification rates are reduced, the animal can still precipitate additional aragonitic shell material at an aragonite saturation index close to unity (Comeau et al., 2009). This information shows that even between species of the same taxonomic suborder, the response to acidification is complicated and often species specific, demonstrating a variation in the susceptibility to reduced calcification.

The extent of seawater acidification from volcanic acid deposition will depend on the magnitude of the eruption, the chemistry and volume of the acids adhering to the particles (or incorporated in precipitating fluids), weather conditions, and the rate of mixing in the water column. If conditions are favorable for rapid and voluminous release of acids through tephra deposition and/or rainfall into ocean surface waters, it might be expected that this deposition would result in transient acidification of the uppermost parts of the water column; an effect that would then be buffered by mixing with the underlying water column. Hence, any potential aragonite undersaturation induced in surface waters would be expected to be restricted to periods of heightened and/or sustained volcanic activity.

The aims of this study are to investigate preliminary observations made during a scientific cruise off-shore Montserrat (Lesser Antilles island arc), which have been briefly documented by Jones and Gislason (2008). Marine sediments collected to the west and south-west of the Soufrière Hills volcano contain distinct horizons of abundant planktic microfossils which are closely associated with layers of recent volcanic ash. This study considers factors which may have lead to such events and their position within the sediments.

\section{Materials and methods}

The scientific cruises of the RRS James Clark Ross (JCR123 May, 2005) and RRS James Cook (JC18 December, 2007) comprised two multidisciplinary studies of the impact of the ongoing volcanic activity on the island of Montserrat (Lesser Antilles) on the surrounding seas. During the course of these cruises over 80 sediment cores were collected from around the island. Many of these cores contain deposits from the two recent dome collapse events in July 2003 and May 2006. The 2003 event erupted $>210 \times 10^{6} \mathrm{~m}^{3}$ of material, most of which entered the ocean east of Montserrat over the course of $\sim 18 \mathrm{~h}$ (Trofimovs et al., 2006). The 2006 event erupted slightly less material, but the resulting pyroclastic and marine gravity flows were more energetic as the collapse occurred over only a few hours.

The ash content of all sites from the RRS James Cook (JC18) cruise were examined and two of the sites were chosen to illustrate the effects of the most recent eruptions upon the marine fauna of the surrounding area. Site JC18-21 lies in $1270 \mathrm{~m}$ of water, well to the southwest of the island (Fig. 1) and did not contain visible ash at the surface. Hence, this area is used as a background site against which to compare the impact of tephra deposition (herein referred to as the control site). A second site, JC18-25 was located in $878 \mathrm{~m}$ of water in an area off the west coast of Montserrat, around $10 \mathrm{~km}$ from the Soufrière Hills volcano (herein referred to as the affected site). This area has experienced significant disturbance from volcanic deposits and contains two distinct layers of ash. It has also been selected as it has experienced ash fall debris only and has not been affected by pyroclastic flows or lahar deposits, leaving the sequential deposits intact.

Megacore samples were retrieved from both sites (JC18-21M and JC18-25M), providing a $10 \mathrm{~cm}$ and $11 \mathrm{~cm}$ record respectively. All sample processing was carried out onboard the ship, while the subsequent faunal analysis was carried out at the University of Plymouth. Using a standard foraminifera method, just over 300 (or as many as were present up to 300) specimens of pteropod and heteropod remains were collected from two size fractions (125$500 \mu \mathrm{m}$ and $>500 \mu \mathrm{m}$ ) at various positions within the cores for each site. This provides information about both abundance and diversity. For analysis of the preservation of pteropod shells, a method (the Limacina Dissolution Index) devised by Gerhardt et al. (2000) and published as a scale by Gerhardt and Henrich (2001) was used. This scale extends from 0 (best; pristine, transparent shells) to 5 (worst; opaque-white, totally lusterless and perforated shells). At selected points in both the control and affected cores, two species of pteropod were analysed using this scale; single representative specimens of Creseis acicula and between 10 and 30 specimens of Limacina inflata, (as in the original designated scale suggested by Gerhardt and Henrich, 2001). Scanning electron microscope (SEM) images were

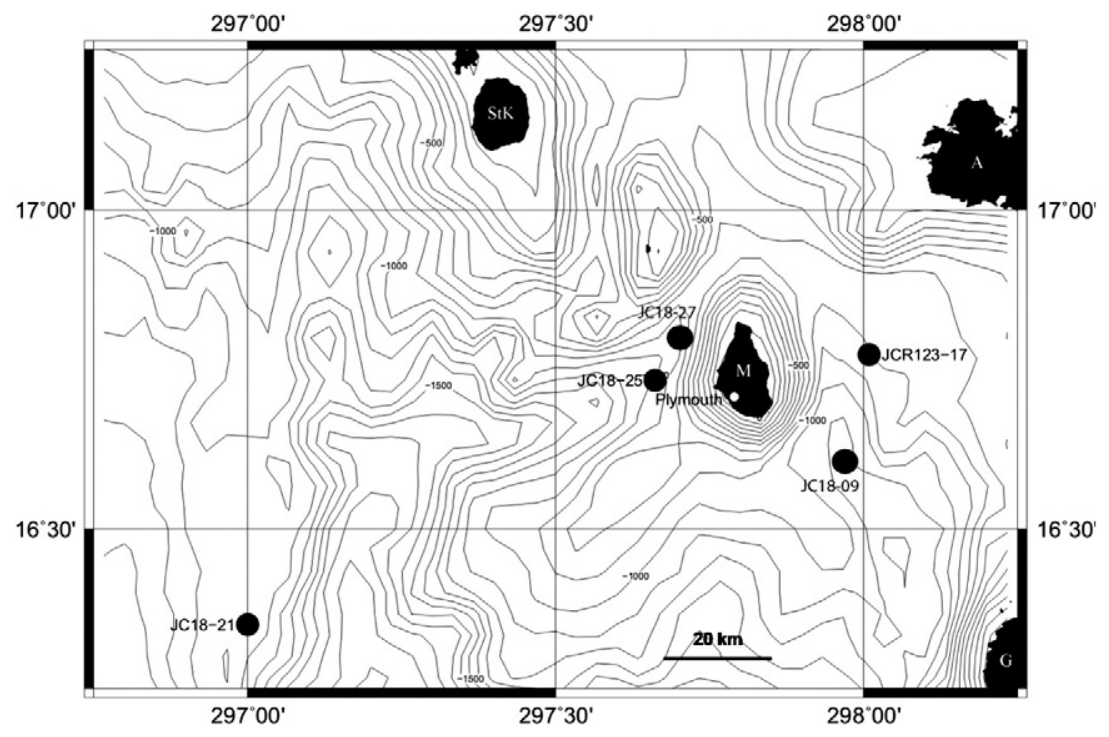

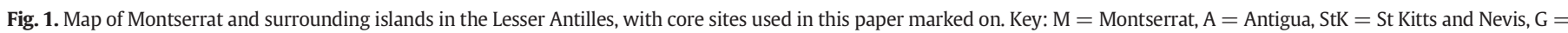
Guadeloupe. 
also obtained of the surface structures of C. acicula specimens to complement the LDX data.

To achieve a first-order estimate of the volume of ash needed to reduce surface water $\mathrm{pH}$ below 7.8 , a series of mixing experiments were conducted using unhydrated ash from the 2003 and 2005 eruptions from the Soufrière Hills volcano on Montserrat, and the 2008 eruption of Chaitén in Chile. Ash from the 2006 eruption was not suitable for the experiments as the eruption occurred during a thunderstorm, compromising the collection of tephra with associated soluble surface coatings. Ash leachate experiments were carried out at the University of Southampton using the same experimental procedure as Jones and Gislason (2008). Surface water collected from the North Atlantic ( $\mathrm{pH}$ 8.08 at $21^{\circ} \mathrm{C}$ ) was pumped at a rate of $60 \pm 2 \mathrm{ml} \mathrm{h}^{-1}$, through a Teflon single-pass, plug flow-through reactor containing unhydrated tephra at $19 \pm 0.2^{\circ} \mathrm{C}$. The reacted solution passed through a $0.2 \mu \mathrm{m}$ cellulose acetate membrane filter into a sample bottle. The difference between this and previous experiments was that $\mathrm{pH}$ and sample weight were continuously monitored, instead of separating the reacted fluid into aliquots for analysis. This allows a range of ash:water ratios to be considered. Each experiment was repeated three times, with varying amounts of ash in the reactor to test a range of mixing scenarios.

\section{Results}

Marine deposits from the Soufrière Hills volcano most commonly occur as pyroclastic density current deposits (Trofimovs et al., 2006), but at sites west of the volcano there are deposits of lahar or air-fall origin from the 2003 and 2006 eruptions that are $\sim 4 \mathrm{~cm}$ and $\sim 3 \mathrm{~cm}$ thick, respectively. At the affected site (Fig. 1), two distinct layers of planktic remains are observed (Fig. 2). The first layer occurs at a depth of $3-5 \mathrm{~cm}$ in the core in a matrix of fine ash from the 2003 volcanic event. This layer is dominated by thecosome pteropods and planktic foraminifera. A similar layer lies at the surface of the 2006 ash at the top of the core ( 0 $1 \mathrm{~cm})$. Both these layers are interbedded with fine ash. This suggests that either their deposition was concurrent with the later stage deposition of the volcanic layers (i.e. the finer particles with a slower settling velocity), or that they settled through a turbid benthic boundary of very recently deposited fine ash that had yet to form a cohesive sedimentary layer. Hence, the deposition of pteropod shells and foraminifera tests began during, or very shortly after, the ash deposition.

\subsection{Diversity and abundance of pteropods}

The typical assemblage of open water pteropods in the vicinity of Montserrat is exemplified by the surface sample $(0-1 \mathrm{~cm})$ from the control core. Pelagic sedimentation rates in this area of the Caribbean Sea are of the order of $2-3 \mathrm{~cm} / \mathrm{kyr}$ (Reid et al., 1996), so the plankton assemblage in this interval is an average for the past $~ 500$ years. Porewater dissolved oxygen levels remain at $>10 \%$ of bottom water values at a depth of $7 \mathrm{~cm}$ in the core, indicating that the sediments in the upper most centimeter have not experienced extensive redox-driven diagenesis. When these observations are coupled with the depth of the core $(1270 \mathrm{~m})$, it suggests that the calcitic foraminifera and the aragonitic pteropods would not be expected to exhibit signs of postdepositional carbonate dissolution. Pteropod shells are very abundant in these sediments (Fig. 3); the size ranges 125-500 $\mu \mathrm{m}$ and $>500 \mu \mathrm{m}$ contain $\sim 20,000$ and 2000 pteropods per gram of sediment $(\mathrm{P} / \mathrm{g})$, respectively. In contrast, the diversity is low, with $L$. inflata and Creseis virgula constricta comprising $34 \%$ and $20 \%$ of the $125-500 \mu \mathrm{m}$ assemblage, respectively. Styliola subula and Limacina spp. are also common. Overall, spiral forms comprise 12 out of 19 of the species present and $61 \%$ of the total individuals. The $>500 \mu \mathrm{m}$ size fraction is also dominated by L. inflata, making up $58 \%$ of the total assemblage, although S. subula and C. virgula virgula are also common. The larger fraction contains a more even spread of morphologies, with 7 spiral species, 6 elongate species, and 5 ornate species, but there are many more spiral individuals (71\%).

The plankton-rich layer at $3-5 \mathrm{~cm}$ in the affected core is mainly composed of pteropods in the $125-500 \mu \mathrm{m}$ size fraction (Fig. 3), with larger specimens dominated by L. inflata. The diversity is comparable to the control assemblage, with $L$. inflata, C. acicula, $C$. virgula constricta, and other Limacina spp. being most abundant. The relative proportion of spiral species (15 of 21) and individuals (63\%) are also comparable to the control assemblage. The $125-500 \mu \mathrm{m}$ size fraction has an average abundance of $107 \mathrm{P} / \mathrm{g}$, with a peak of $120 \mathrm{P} / \mathrm{g}$ between 4 and $5 \mathrm{~cm}$. The surface layer $(0-1 \mathrm{~cm})$ of the affected core is also largely composed of individuals in the smaller size fraction, with
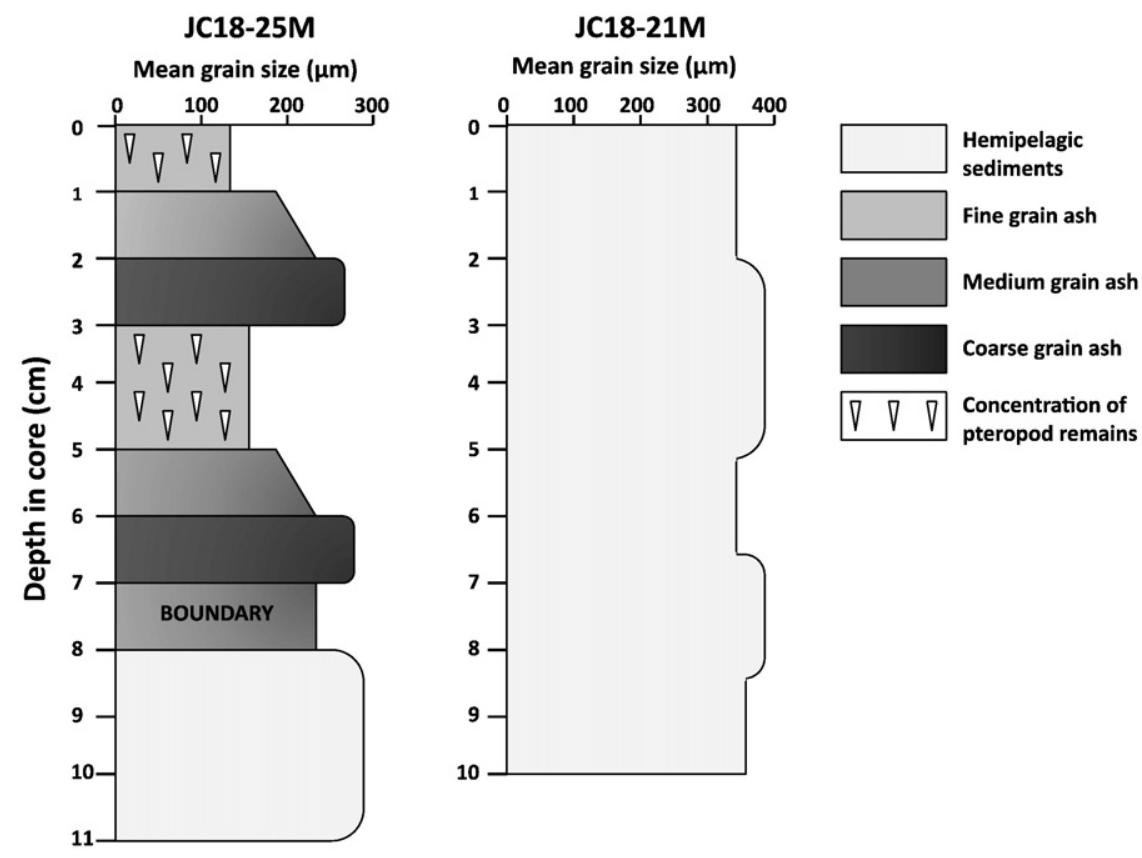

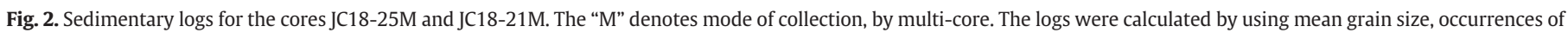
fauna, and laboratory and ship board observations. 
Mean grain size

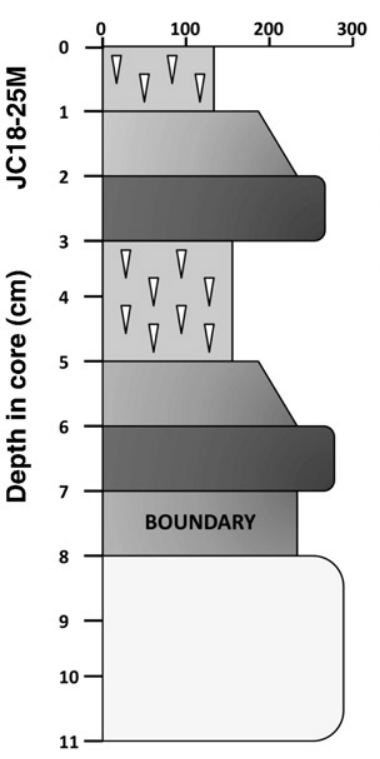

Abundance (pteropods per gram)
Diversity (number of species)
Main species composition (\%)

50

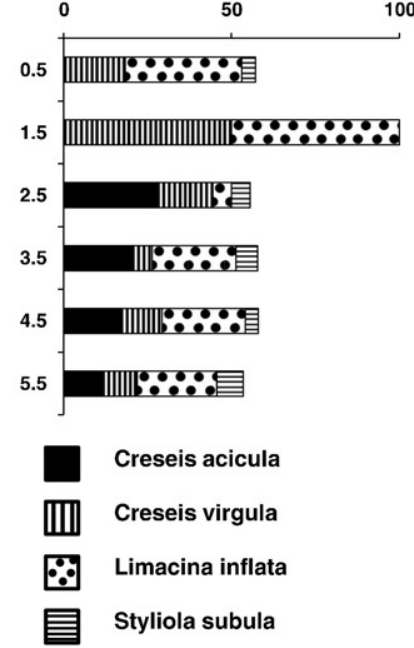

LDX

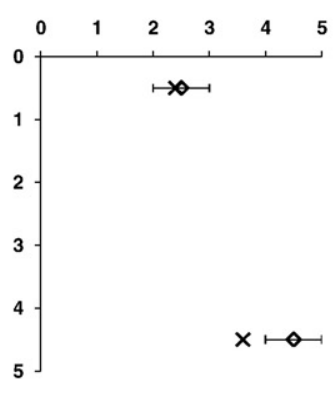

$\diamond C$. acicula

$X L$. inflata
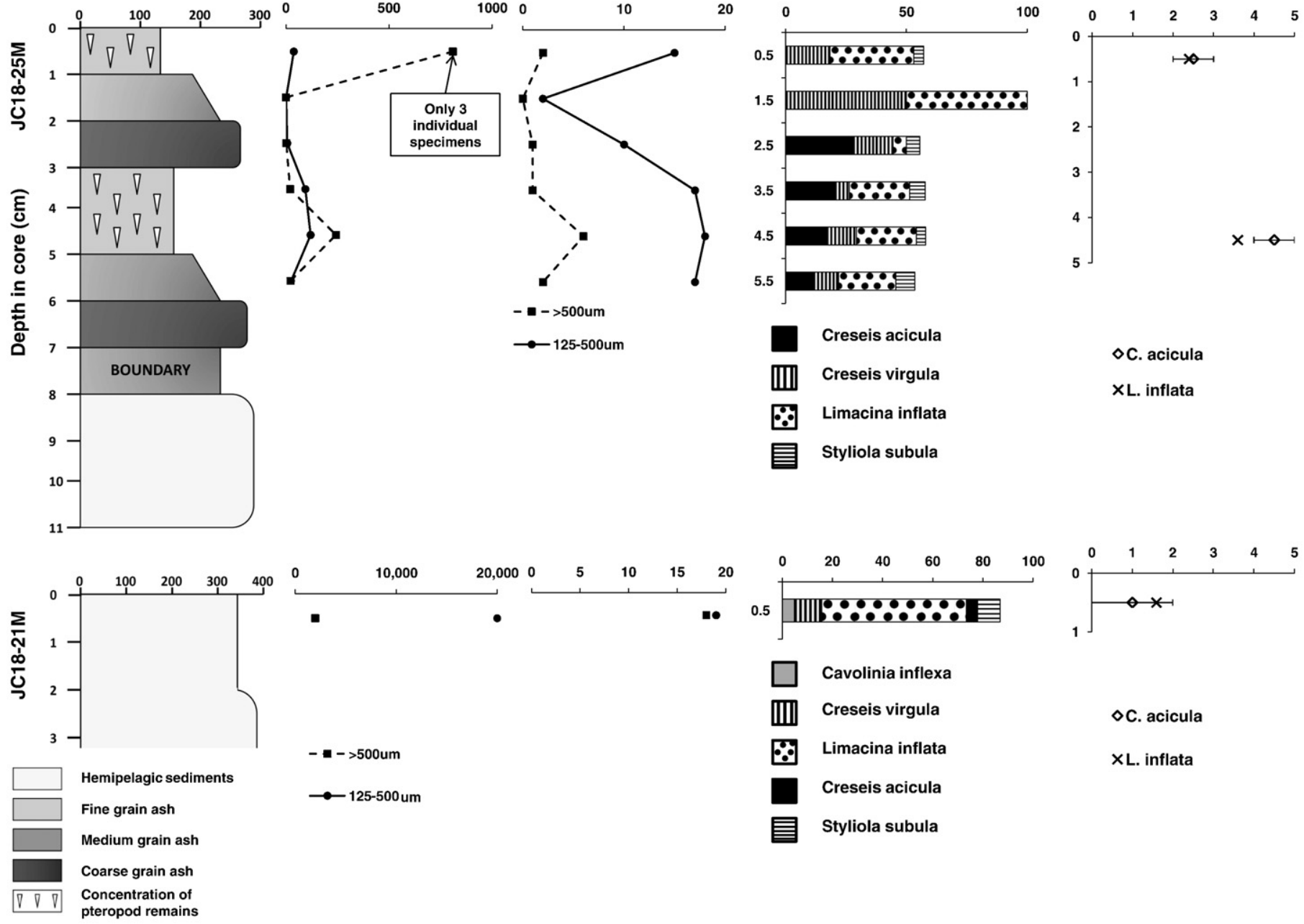

$\diamond$ C. acicula

$X$ L. inflata

Styliola subula

Fig. 3. Pteropod abundance, diversity, percentage of main species and Limacina Dissolution Index (LDX) values for the affected core (JC18-25M) and the control core (JC18-21M).

very few pteropods found $>500 \mu \mathrm{m}$ in size (Fig. 3). Again, the assemblage is made up largely of spiral species and individuals (11 out of 14 and 76\%, respectively), and is dominated by L. inflata and C. virgula constricta. The abundance of pteropods in this layer is much lower, with only $38 \mathrm{P} / \mathrm{g}$ in the $125-500 \mu \mathrm{m}$ fraction, although this is principally due to dilution by the ash matrix, which is denser than the planktic remains.

\subsection{Preservation of pteropods}

Representative specimens of $C$. acicula from the control site show excellent preservation (LDX scale $0-2$ ); the surface structures are generally not etched or damaged and the wall structures are strong and intact (Fig. 4). Similarly, specimens of L. inflata have an average LDX of 1.6. In contrast, specimens of $C$. acicula collected from the 3-5 cm layer of the affected core show poor preservation (LDX scale $4-5$ ). The shell surfaces have been entirely removed by corrosion, exposing the aragonite rods beneath, while the wall structures have been badly damaged and in many instances have separated in two (Fig. 4). During preparation for the SEM study, shells from the $3-5 \mathrm{~cm}$ layer also crumbled easily and were far easier to break than specimens from the control site. Again, specimens of $L$. inflata are consistent with this level of preservation, providing an average LDX of 3.6. Pteropods from the upper layer of the affected core also showed poor preservation (LDX scale 2-3), although they were better preserved than in the $3-5 \mathrm{~cm}$ layer. The surfaces of the shells are partially dissolved, etched and damaged. Specimens of $L$. inflata provide an average LDX of 2.4.

\subsection{Ash leachate experiments}

Data from previous ash leachate experiments has been published by Jones and Gislason (2008). Resulting pH changes caused by the addition of Montserrat ash to de-ionized water, Atlantic Ocean water and Southern Ocean water in this previous study can be seen in Table 1. Additionally, Table 1 shows the amount of sulfate $\left(\mathrm{SO}_{4}^{2-}\right)$ released per gram of ash for the three water types. These values can be transformed into the amount of sulfur released, giving $0.4,2.28$ and $2.7 \mathrm{mg}$ of sulfur released per gram of ash for de-ionized water, Atlantic Ocean surface water and Southern Ocean surface water, respectively. Using values published by Trofimovs et al. (2006), $210 \times 10^{6} \mathrm{~m}^{3}$ of volcanic material was produced by the 2003 eruption of the Soufrière Hills volcano. If a typical density of $2.5 \mathrm{~g} \mathrm{~cm}^{-3}$ is used, this gives $5.25 \times 10^{14} \mathrm{~g}$ of volcanic material erupted. Assuming all of this material had the same coating of sulfur as that measured by Jones and Gislason (2008), then the amount of sulfur on the particle surfaces, as predicted for each water type, would be $0.21,1.2$ and 1.42 million tons. While the larger size fraction particles are likely to have less adsorbed sulfur, these calculations do not include the sulfur deposited by other processes such as precipitation. Trofimovs et al. (2006) also suggest that $90 \%$ of all volcanic material directly entered the waters around Montserrat, which would mean that the majority of this 

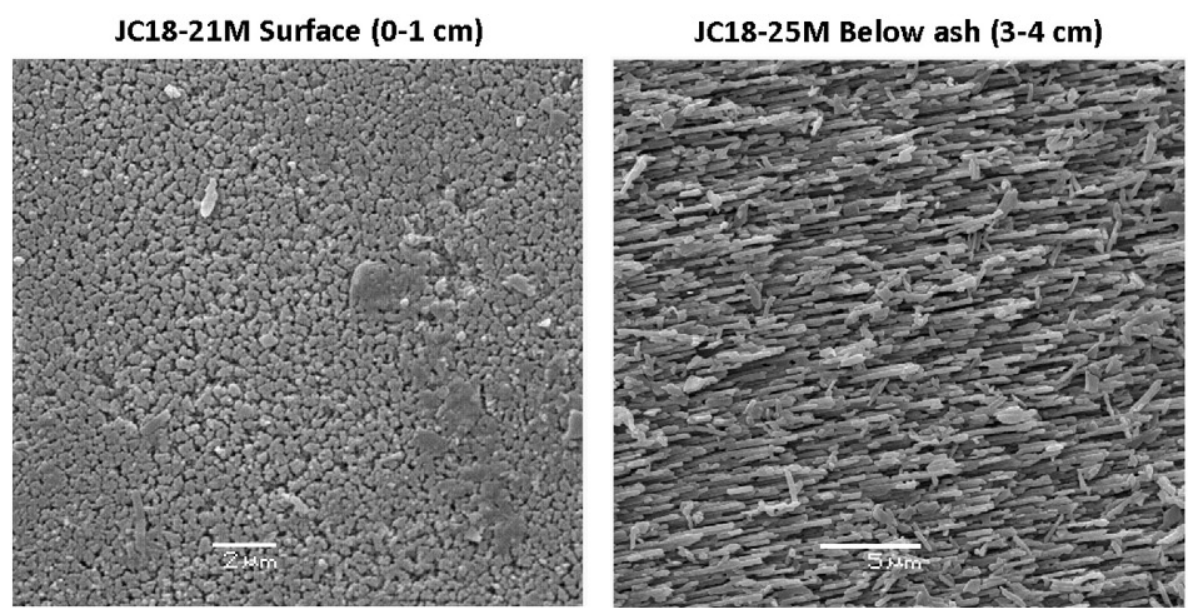

\section{(a) Surface Structure}
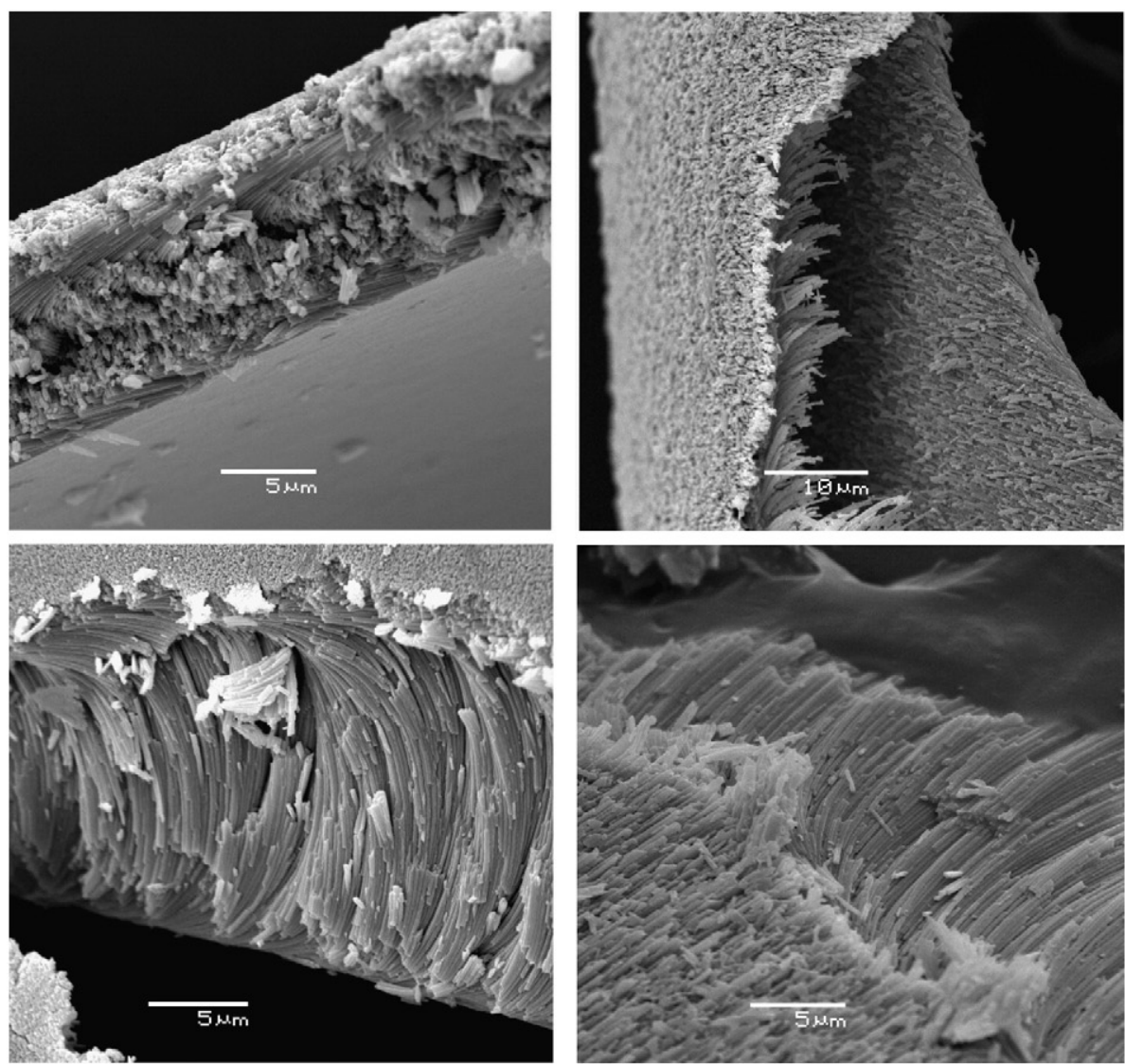

(b) Wall Structure

Fig. 4. SEM images of the pteropod C. acicula. (a) Surface structures and (b) wall structures of shells from the control assemblage (JC18-21M 0-1 cm) compared to those from below the 2006 ash layer (JC18-25M 3-5 cm).

adsorbed sulfur was transported straight to the sea. Results from the mixing experiments carried out for this study show variations between ash from different events of the Soufrière Hills volcano, which can be seen in Fig. 5. These results show that ash:water mass ratios of 0.025 and 0.014 are required to reduce the $\mathrm{pH}$ to below 7.8 and hence achieve aragonite undersaturation by the 2003 and 2005 Montserrat tephras respectively. However, as the reactivity of adsorbed material appears to decrease over time (Jones and Gislason, 2008; Duggen et al., 2009), the observed difference between the samples may not reflect the true coatings at the time of deposition.

\section{Discussion}

\subsection{Abundance and diversity of pteropods}

There is often a strong decoupling between the planktic assemblage of the water column and that found within surface sediments. Although there are no plankton data for the oceans around Montserrat, studies have been conducted in the Western Caribbean Sea (Suárez-Morales and Gasca, 1998; Parra-Flores and Gasca, 2009) and offshore Barbados (Wells, 1975, 1976). In the case of the latter studies, the euthecosome 
Table 1

Results of ash mixing experiments using Montserrat ash from the 2003 event of the Soufrière Hills volcano (Jones and Gislason, 2008).

\begin{tabular}{llll}
\hline & $\begin{array}{l}\text { De-ionized } \\
\text { water }\end{array}$ & $\begin{array}{l}\text { Atlantic Ocean } \\
\text { surface water }\end{array}$ & $\begin{array}{l}\text { Southern Ocean } \\
\text { surface water }\end{array}$ \\
\cline { 2 - 4 }$(\mathrm{min})$ & Resulting water pH & \\
\hline 25 & & & \\
75 & 4.66 & 6.89 & 7.29 \\
125 & 5.74 & 7.4 & 7.54 \\
175 & 5.7 & 7.87 & 7.62 \\
225 & 5.9 & 7.92 & 7.77 \\
275 & 5.73 & 7.9 & 7.81 \\
325 & 5.83 & 7.91 & 7.91 \\
375 & 6.04 & 7.9 & 7.87 \\
425 & 6.21 & 7.91 & 7.96 \\
475 & 6.2 & 7.92 & 7.94 \\
1365 & 6.16 & 7.96 & 7.93 \\
1415 & - & 7.99 & 7.88 \\
$\mathrm{SO}_{4}^{2-}$ released within $8 \mathrm{~h}$ & 12.5 & 8.01 & 7.95 \\
$(\mu \mathrm{mol} / \mathrm{g}$ of ash) & & 71.2 & 84.2 \\
\hline
\end{tabular}

pteropod assemblage in the upper layers of sediment accurately reflects the species composition and relative abundance of the overlying waters (Wells, 1975). Although the relative abundances of each species vary, most of the species found in the surface sediments of the control core are represented in these studies, and the dominant species are in most cases similar. For example, all of the studies found $L$. inflata to be by far the most abundant species; followed by Creseis spp. (including C. acicula and various sub-species of $C$. virgula, which is the second most abundant species in the combined size fractions from the control core). It is noteworthy that $S$. subula is abundant in the sediments of the control core, but is not well represented in the plankton studies. This may be due to net avoidance by the pteropods or a large mesh size used in the studies. For example, Parra-Flores and Gasca (2009) used a net mesh of $355 \mu \mathrm{m}$, which may have allowed the slender $S$. subula shells to pass through. Conversely, Limacina trochiformis is well-represented in the plankton studies, but only contributes $3 \%$ of the control assemblage. This discrepancy may be due to patchy distributions of pteropod species caused by local water circulation patterns; for example, Suárez-Morales and Gasca (1998) found that the pteropod community of the Mexican Caribbean Sea contains a mixture of both neritic and oceanic species.

The core collected from the affected site contains two deposits of abundant planktic remains. Although the abundance of pteropods is higher in the control core, the pelagic sedimentation rate of $\sim 2-3 \mathrm{~cm} /$ kyr (Reid et al., 1996) means that the number of shells at the control site

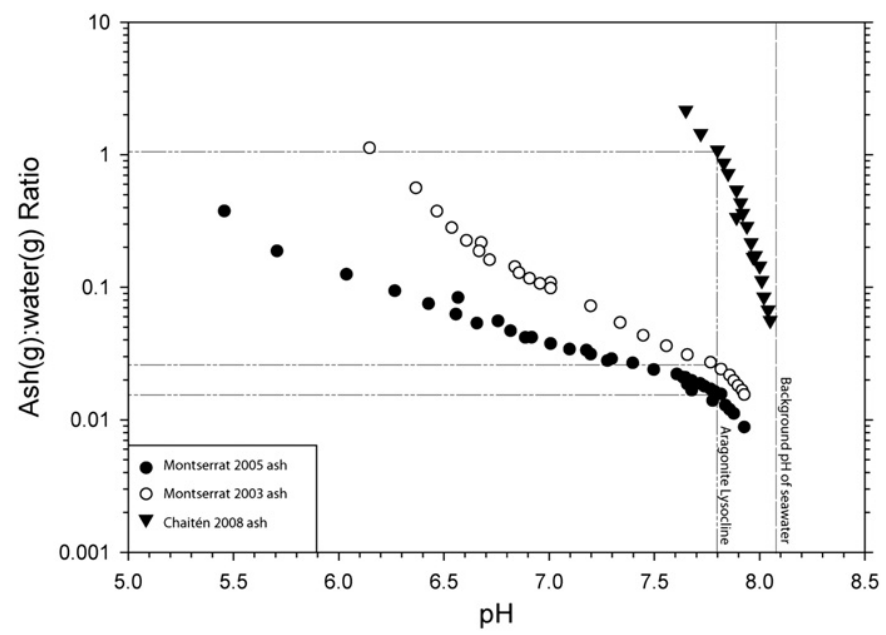

Fig. 5. Results of mechanical mixing experiments using two samples of unhydrated ash from Montserrat (2003 and 2005), and a sample from Chaitén in Chile (2008). has built up over many hundreds of years, whereas the planktic remains in the 3-5 cm layer of the affected core must have accumulated within 34 months at most (the time between the 2003 and 2006 eruptions). Similarly, the $0-1 \mathrm{~cm}$ pteropod-rich layer in the affected core must have accumulated in less than 19 months - the interval between the dome collapse event that generated the tephra layer and the sampling date. Hence, there can be little doubt that there was a rapid increase in the export of planktic organisms during, or immediately after, the dome collapse events and associated volcanic activity.

There are several lines of evidence to suggest that the two plankticrich layers in the affected core resulted from increased mortality of a standing crop of planktic organisms, rather than increased productivity and sedimentation due to nutrient addition. Firstly, if the planktic-rich layers arose from an increase in production, then both layers would be expected to contain a high proportion of phytoplankton remains, whereas they are both dominated by pteropods and planktic foraminifera. High proportions of phytoplankton would be seen as pale carbonate sediment, which was not observed during collection. Secondly, the size distribution of the pteropods observed in the planktic-rich layers favors a sudden increase in mortality. Although the higher concentrations of smaller individuals observed in the affected core compared to the control core may be due to a change in the conditions governing the growth rates and/or life expectancies of individual pteropods, the fact that the larger pteropods are concentrated toward the base of the 3-5 cm layer (Fig. 2) is suggestive of a mortality event, as larger tests have higher settling velocities. If the planktic-rich layers had arisen in response to a phytoplankton bloom, then one would expect to see reverse grading in the pteropod sizes as short-lived immature individuals fell to the sea floor ahead of the longer-lived large specimens. Finally, the over-representation of smaller individuals in the planktic-rich layers relative to the control site is consistent with sudden mortality of a standing crop, in which immature individuals will be more abundant than the assemblage resulting from the deaths and export of tests from a population progressing to their natural life expectancy.

\subsection{Preservation of pteropods}

Overall, the evidence presented above is strongly supportive of the sudden mortality and sedimentation of a natural population of pteropods in close association with volcanic processes resulting from dome collapse events. The preservation state of pteropod shells from the affected core indicates that they have undergone significant dissolution. Interaction with the aragonite compensation depth (ACD) and/or aragonite lysocline can be discounted as a cause for the poor preservation of these pteropod shells. Although water chemistry around the Lesser Antilles island arc is complicated by water masses from several origins flowing between the islands, Gerhardt and Henrich (2001) found that towards the north of the arc, an area which encompasses Montserrat, the preservation of $L$. inflata is generally very good. This is due to a large influx of Upper North Atlantic Deep Water which flows through the nearby Anegada Passage. Gerhardt and Henrich (2001) place the aragonite saturation depth at $2000 \mathrm{~m}$ and the ACD at $3800 \mathrm{~m}$ water depth in this area. It is also important to note that the affected core was collected from a shallower depth $(878 \mathrm{~m})$ than the control core (1270 m) which contains well-preserved pteropod remains. In addition, none of the 10 CTD casts around the island showed any evidence that the water column was undersaturated with respect to aragonite over the sampled depth range (0-1946 m). GLODAP data (Key et al., 2004) for the Caribbean Sea also shows that both sites are above the aragonite lysocline (Fig. 6).

It is possible that the shells underwent dissolution after arriving at the seafloor. The effect of the breakdown of organic matter can be discounted as total carbon concentrations within 10 ash layers recovered from the JC18 cruise consistently show $\mathrm{C}<1 \mathrm{wt} . \%$, with organic carbon $<0.1 \mathrm{wt} . \%$ within the ash layers. This indicates that organic matter is diluted by the deposited ash and hence plays a minor role in diagenesis. However, 
porewater $\mathrm{pH}$ values at site JCR123-17 (Fig. 1) show $\mathrm{pH}$ values falling to $<7.4$ below depths of $\sim 1 \mathrm{~cm}$ within the 2003 ash layer (Fig. 7) in response to diagenesis of the volcanic material. Moreover, pteropods collected beneath ash layers in Andaman Sea sediments show poorer preservation than those collected from sediments from the same water depth, but not containing ash (Bhattacharjee, 2005). The poorer preservation of pteropods from the $3-5 \mathrm{~cm}$ layer in the affected core compared to the surface layer in the same core is therefore likely to be the continued dissolution of the shells after burial. However, pteropod shells collected at $1119 \mathrm{~m}$ water depth from a further site, JC18-09 (Fig. 1), show that dissolution from volcanically affected pore waters only has a minimal effect on the preservation. The 2006 dome collapse at this site is represented by a pyroclastic density current that scoured the sea bed and incorporated pre-eruption pteropod shells from shallower shelf sediments. Despite the shells being physically fragmented during this transport process, and thus more susceptible to dissolution, pteropod shell fragments from the surface layer of this core display an LDX preservation of $1-2$. This observation indicates that the effect of volcanic ash on the pore water was insufficient to degrade pteropod shells.

\subsection{Potential impact of acid deposition}

As noted above, deposition of volcanic eruption products have the potential to cause acidification of surface waters, although this potential varies considerably between different volcanoes and/or volcanic deposition events (Jones and Gislason, 2008). Calculated ash:water mass ratios of 0.025 and 0.014 are required to achieve aragonite undersaturation by the 2003 and 2005 Montserrat tephras, respectively (Fig. 5). In contrast, ash from the Chaitén eruption has much less adsorbed acids, such that aragonite undersaturation would require a 1:1 ash/seawater ratio. An indication of the potential impact of the 2003 and 2006 eruptions can be made by making simple assumptions - i.e. that the tephra was added to the surface water over a short time period and was well-mixed in the surface layer. Under these conditions, the $3 \mathrm{~cm}$ thick ash layer observed in core JC18-25 could have caused the upper $5.1 \mathrm{~m}$ of the water column to become undersaturated with respect to aragonite (assuming that the ash had the same adsorbed acid load as the 2005 ash), and the $4 \mathrm{~cm}$ thick layer produced by the 2003 eruption could have caused aragonite undersaturation in the upper $3.8 \mathrm{~m}$ of the water column.

Clearly, there are important caveats to these calculations. The assumption that the tephra was rapidly added to the surface water is not unreasonable, as both dome collapse events took place over the course of a few hours. The kinetics of adsorbed ash dissolution versus sinking

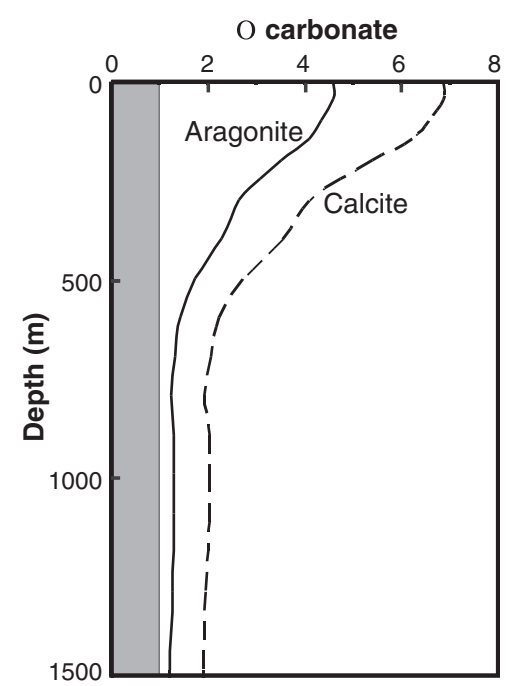

Fig. 6. Carbonate saturation profile of the Caribbean Sea from GLODAP site $17.03^{\prime} \mathrm{N}$, 66W (Key et al., 2004).

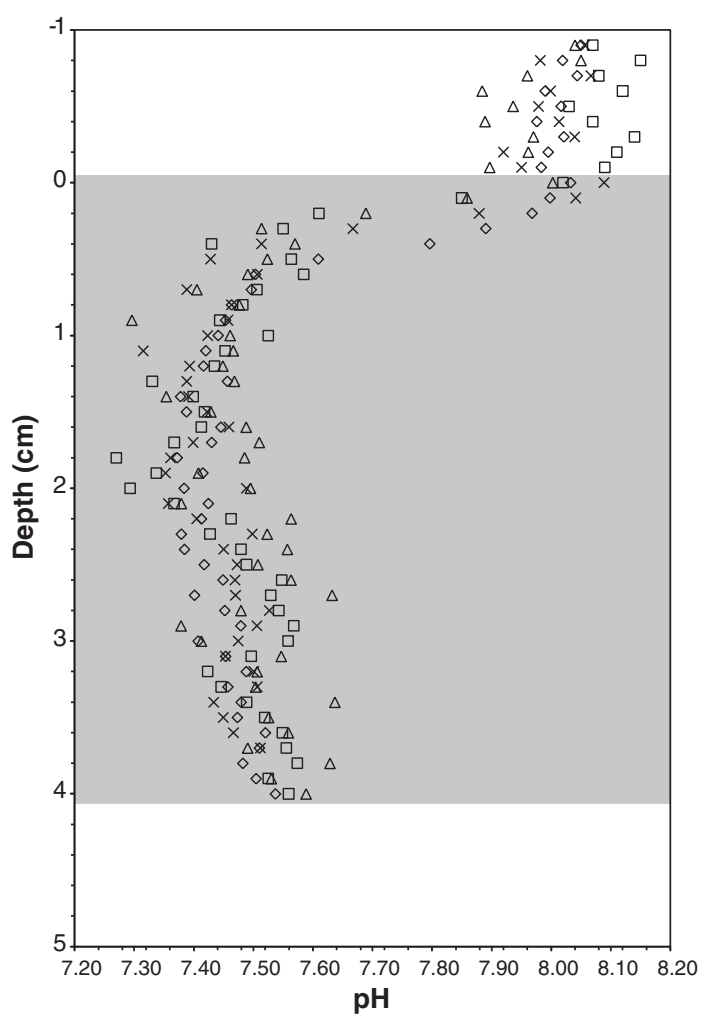

Fig. 7. In situ pH measurements of pore waters from sediment core JCR123-17 to the east of Montserrat in $\sim 850 \mathrm{~m}$ water depth. The gray shading denotes ash deposited between 1995 and 2005 at the site, dominantly from the 2003 eruption. Different symbols reflect multiple profiles in the same core.

rate of the particles can be constrained from the experimental data (Fig. 5) and Stokes law settling velocities. The average size fraction of the volcanic sediment in the affected core is around $\Phi 5(\sim 0.031 \mathrm{~mm})$, and is poorly sorted. Assuming a spherical shape and a density of $2.65 \mathrm{~g} \mathrm{~cm}^{-3}$, the average terminal (settling) velocity of the tephra is $\sim 0.8 \mathrm{~mm} \mathrm{~s}^{-1}$. Hence the tephra would take $\sim 2 \mathrm{~h}$ to settle through the upper $5 \mathrm{~m}$ of the water column, by which time $99 \%$ of the ash leachate would have dissolved (Jones and Gislason, 2008). However, the observation that pteropods are still capable of shell calcification at pH 7.8 (Comeau et al., 2009) suggests that the $\mathrm{pH}$ would have to be reduced even further to account for both the quantity and preservation state of pteropods at the affected site.

It is likely however, that the experiments have underestimated the extent of acidification induced by ash deposition in seawater as it is very difficult to collect unhydrated ash. Interaction of fresh tephra with atmospheric moisture and/or associated rainfall that accompanies volcanic eruptions means that tephra collected after it has fallen to ground seldom preserves its original adsorbed phase. In addition, simultaneous wet and dry depositions of volcanic acids into the oceans would further increase the acidity of surface waters. For example, the Montserrat Volcano Observatory has measured rainfall in Plymouth (Fig. 1) with a $\mathrm{pH}$ as low as 1.8 . This would have been particularly important during the 2006 eruption, which occurred during a heavy storm. However, without the fortuitous (and hazardous) collection of ash and rain fallout at the height of the eruption the true scale of acid deposition is difficult to constrain more accurately. Nevertheless, if acidification of surface waters is in part responsible for the quantity and preservation state of pteropods in the affected core, then the coeval contribution of acid from wet and dry deposition of hydrated volcanic gases (principally $\mathrm{H}_{2} \mathrm{SO}_{4}$ from $\mathrm{SO}_{2}$ ) must have been greater than that derived from leaching of tephra particles alone. 


\subsection{Alternative causes for pteropod mortality}

Other processes that might cause pteropod mortality related to volcanic events arise from the physical properties of the ash. The species Diacria quadridentata is known to respond to any disturbance by withdrawing into its shell and passively sinking (Bé and Gilmer, 1977). A constant fall of ash over several hours would almost certainly have initiated such a response, with the result that the pteropods may have remained in their shells and sunk below the pycnocline and been unable to return to the surface. Some species may have had a similar response to the volcanic induced reduction in $\mathrm{pH}$; the species Limacina helicina displayed a marked decrease in active swimmers when subjected to reduced pH conditions (Comeau et al., 2009). Pteropods feed on smaller plankton by producing mucous nets that are much larger than their shell. If they fail to detach from this net during ash deposition, entrainment of relatively dense tephra in the net could cause them to become negatively buoyant. In addition, ash particles could clog the gills of the pteropods and cause suffocation. Although reasonable, these alternative causes of mortality do not explain the dissolution of the pteropod shells. The large abundance of pteropods in the sediments of the affected core may be related to the diurnal vertical migration exhibited by many euthecosome pteropod species which leads to a large abundance of pteropods in surface waters during darkness (Bé and Gilmer, 1977; Parra-Flores and Gasca, 2009). Both the 2003 and 2006 eruptions of the Soufrière Hills volcano occurred at night, affecting the surface waters at a time when the largest density of pteropods would have been present.

Finally, although surface water acidification by dissolution of adsorbed tephra coatings may not be sufficient to be the sole cause of the pteropod mortality, the response of planktonic organisms of all kinds to potentially toxic species released during dissolution of the tephra coatings is much less well-constrained. It may be noteworthy that mussel farming on Chiloé Island, near Chaitén, was particularly bad during 2008/2009 immediately after the 2008 eruption, and appears to be related to a decrease in the phytoplankton population close to the volcano (A. Amigo, pers. comm.). Given that the Montserrat ash is more reactive than that from Chaitén(Fig. 5), this process might be expected to be more important around Montserrat and could account for the presence of both pteropods and foraminifera in the affected sediments.

Montserrat is host to a relatively small volcano $\left(<1 \mathrm{~km}^{3}\right.$ magma erupted in the past 14 years), other explosive volcanoes have been much larger. For example, the 1815 Tambora (Indonesia) eruption expelled $50 \mathrm{~km}^{3}$ of pyroclastic material in a single event (Oppenheimer, 2003), and there are examples in the geological record of "supereruptions" with erupted volumes exceeding $4000 \mathrm{~km}^{3}$ of dense magma (Mason et al., 2004). A $1000 \mathrm{~km}^{3}$ super-eruption could blanket an area of $10^{7} \mathrm{~km}^{2}$ with $10 \mathrm{~cm}$ of ash (Jones et al., 2007). The potential global significance of explosive volcanism on plankton depends on the mechanism by which the volcanic event causes mortality and whether this process or processes are present in each eruption. If the mechanism of mortality was due to surface water acidification or release of toxic metals, then the impact of a super-eruption would be critically dependent on the magma and volatile phase compositions. The minimal ash-leachate release observed from the Chaitén ash (Fig. 5) is particularly interesting as the eruption was rhyolitic (>70 wt.\% $\mathrm{SiO}_{2}$ ), comparable in composition to most large volume explosive eruptions. If this ash-leachate release is typical of rhyolitic ashes, then one would expect a relatively low acidification impact from rhyolitic ash deposition into the ocean. However, if the mortality around Montserrat is due to other physical disturbances of pteropods in surface waters, the type of ash would be of lesser significance than the overall scale of the eruption.

\section{Conclusions}

Affected core JC18-25M contains two distinct layers of pteropod and planktic foraminifera remains produced by the rapid and significant mortality of a standing crop of living organisms. Whereas most previous studies of the impact of volcanism on marine ecosystems have concentrated on their role in supplying limiting nutrients to instigate increases in primary productivity (e.g. Frogner et al., 2001; Duggen et al., 2007), to our knowledge, this study presents the first direct evidence that explosive volcanism can have a detrimental effect on planktic fauna in marine surface water adjacent to a volcano. The mechanism by which this mortality was induced is not clear, but there is some evidence that surface water acidification by dissolution of surface coatings on tephra and/or dry and wet depositions of volcanic gases may have played a role. Other viable causes of the mortality event include release of toxic metals during reaction of the tephra with seawater, and the physical effects of fine-grained ash. Regardless of the precise mortality mechanism, the fact that pteropods and planktic foraminifera are key constituents within the food-web (Hunt et al., 2008), suggests that large explosive eruptions could cause significant disruption of marine ecosystems.

\section{Acknowledgements}

The cruises of the RRS James Clark Ross JCR123 and the RRS James CookJC18 were supported by NERC grant proposal codes NER/A/S/2002/ 00963JCR and NE/D004020/1 respectively. The authors would like to thank the valuable assistance of the shipboard scientists and crews of the JCR-123 and JC-18 cruises. Polly Hill is thanked for the donation of North Atlantic seawater, Sue Loughlin and Alvaro Amigo for the collection and donation of ash samples, Sigurdur Gislason for the use of Teflon plug reactors, and the staff of the Montserrat Volcanic Observatory for the provision of precipitation data. M.B.H., C.W.S. and J.K.F. acknowledge the support of a research grant (F/00 568/P) from the Leverhulme Trust.

\section{References}

Bé, A.W.H., Gilmer, R.W., 1977. A zoogeographic and taxonomic review of Euthecosomatous pteropoda. In: Ramsay, A.T.S. (Ed.), Oceanic Micropaleontology, vol. 1. Academic Press, New York, pp. 733-808.

Bhattacharjee, D., 2005. Pteropod preservation profiles in seabed sediments off Middle Andaman Island in Andaman Sea. Indian Journal of Marine Sciences 34, 259-266.

Brand, L.E., Sunda, W.G., Guillard, R.R.L., 1986. Reduction of marine phytoplankton reproductive rates by copper and cadmium. Journal of Experimental Marine Biology and Ecology 96, 225-250.

Bruland, K.W., Donat, J.R., Hutchins, D.A., 1991. Interactive influences of bioactive trace metals on biological production in oceanic waters. Limnology and Oceanography 36, 1555-1577.

Comeau, S., Gorsky, G., Jeffree, R., Teyssié, J.-L., Gattuso, J.-P., 2009. Impact of ocean acidification on a key Arctic pelagic mollusc (Limacina helicina). Biogeosciences 6, 1877-1882.

Comeau, S., Jeffree, R., Teyssié, J.-L., Gattuso, J.-P., 2010a. Response of the Arctic Pteropod Limacina helicina to projected future environmental conditions. PLoS ONE 5, e11362.

Comeau, S., Gorsky, G., Alliouane, S., Gattuso, J.-P., 2010b. Larvae of the pteropod Cavolinia inflexa exposed to aragonite undersaturation are viable but shell-less. Marine Biology 157, 2341-2345.

Croot, P.L., Moffett, J.W., Brand, L., 2000. Production of extracellular Cu complexing ligands by eucaryotic phytoplankton in response to $\mathrm{Cu}$ stress. Limnology and Oceanography 45, 619-627.

Duggen, S., Croot, P., Schacht, U., Hoffmann, L., 2007. Subduction zone volcanic ash can fertilize the surface ocean and stimulate phytoplankton growth: evidence from biogeochemical experiments and satellite data. Geophysical Research Letters 34 L01612.

Duggen, S., Olgun, N., Croot, P., Hoffmann, L., Dietze, H., Teschner, C., 2009. The role of airborne volcanic ash for the surface ocean biogeochemical iron-cycle: a review. Biogeosciences 6, 6441-6489.

Feely, R., Sabine, C., Lee, K., Berelson, W., Kleypas, J., Fabry, V., Millero, F., 2004. Impact of anthropogenic $\mathrm{CO}_{2}$ on the $\mathrm{CaCO}_{3}$ system in the Oceans. Science 305, 362-366.

Frogner, P., Gislason, S.R., Oskarsson, N., 2001. Fertilizing potential of volcanic ash in ocean surface water. Geology 29, 487-490.

Frogner-Kockum, P.C., Herbert, R.B., Gislason, S.R., 2006. A diverse ecosystem response to volcanic aerosols. Chemical Geology 231, 57-66.

Gattuso, J.-P., Frankignoulle, M., Bourge, I., Romaine, S., Buddemeier, R., 1998. Effect of calcium carbonate saturation of seawater on coral calcification. Global and Planetary Change 18, 37-46.

Gerhardt, S., Henrich, R., 2001. Shell preservation of Limacina inflata (Pteropoda) in surface sediments from the Central and South Atlantic Ocean: a new proxy to determine the aragonite saturation state of water masses. Deep-Sea Research 48, 2051-2071. 
Gerhardt, S., Groth, H., Rühlemann, C., Henrich, R., 2000. Aragonite preservation in late Quaternary sediment cores on the Brazilian Continental Slope: implications for intermediate water circulation. International Journal of Earth Sciences 88, 607-618.

Hall-Spencer, J.M., Rodolfo-Metalpa, R., Martin, S., Ransome, E., Fine, M., Turner, S.M., Rowley, S.J., Tedesco, D., Buia, M.-C., 2008. Volcanic carbon dioxide vents show ecosystem effects of ocean acidification. Nature 454, 96-99.

Hunt, B.P.V., Pakhomov, E.A., Hosie, G.W., Siegel, V., Ward, P., Bernard, K., 2008. Pteropods in Southern Ocean ecosystems. Progress in Oceanography 78, 193-221.

Jones, M.T., Gislason, S.R., 2008. Rapid releases of metal salts and nutrients following the deposition of volcanic ash into aqueous environments. Geochimica et Cosmochimica Acta 72, 3661-3680.

Jones, M.T., Sparks, R.S.J., Valdes, P.J., 2007. The climatic impact of supervolcanic ash blankets. Climate Dynamics 29, 553-564.

Key, R.M., Kozyr, A., Sabine, C.L., Lee, K., Wanninkhof, R., Bullister, J.L., Feely, R.A., Millero, F.J., Mordy, C., Peng, T.-H., 2004. A global carbon climatology: results from Global Data Analysis Project (GLODAP). Global Biogeochemical Cycles 18, GB4031.

Langdon, C., Takahashi, T., Sweeney, C., Chipman, D., Goddard, J., Marubini, F., Aceves H., Barnett, H., Atkinson, M., 2000. Effect of calcium carbonate saturation state on the calcification rate of an experimental coral reef. Global Biogeochemical Cycles 14, 639-654.

Mason, B.G., Pyle, D.M., Oppenheimer, C., 2004. The size and frequency of the largest explosive eruptions on Earth. Bulletin of Volcanology 66, 735-748.

Moffett, J.W., Brand, L.E., 1996. Production of strong, extracellular Cu chelators by marine cyanobacteria in response to Cu stress. Limnology and Oceanography 41, 388-395.

Mucci, A., 1983. The solubility of calcite and aragonite in seawater at various salinities, temperatures and 1 atmosphere total pressure. American Journal of Science 238, 780-799.

Oppenheimer, C., 2003. Climatic, environmental and human consequences of the largest known historic eruption: Tambora volcano (Indonesia) 1815. Progress in Physical Geography 27, 230-259.

Orr, J., Fabry, V., Aumont, O., Bopp, L., Doney, S., Feely, R., Gnanadesikan, A., Gruber, N., Ishida, A., Joos, F., Key, R., Lindsay, K., Maier-Reimer, E., Matear, R., Monfray, P., Mouchet, A., Najjar, R., Plattner, G.-K., Rodgers, K., Sabine, C., Sarmiento, J., Schlitzer,
R., Slater, R., Totterdell, I., Weirig, M.-F., Yamanaka, Y., Yool, A., 2005. Anthropogenic ocean acidification over the twenty-first century and its impact on calcifying organisms. Nature 437, 681-686.

Oskarsson, N., 1980. The interaction between volcanic gases and tephra: fluorine adhering to tephra of the 1970 Hekla eruption. Journal of Volcanology and Geothermal Research 8, 251-266.

Parra-Flores, A., Gasca, R., 2009. Distribution of pteropods (Mollusca: Gastropoda: Thecosomata) in surface waters $(0-100 \mathrm{~m})$ of the Western Caribbean Sea (winter 2007). Revista de Biología Marina y Oceanografia 44, 647-662.

Reid, R.P., Carey, S.N., Ross, D.R., 1996. Late Quaternary sedimentation in the Lesser Antilles island arc. Geological Society of America Bulletin 108, 78-100.

Riebesell, U., Zondervan, I., Rost, B., Tortell, P., Zeebe, R., Morel, F., 2000. Reduced calcification of marine phytoplankton in response to increased atmospheric $\mathrm{CO}_{2}$. Nature 407, 364-367.

Rose, W.I., 1977. Scavenging of volcanic aerosol by ash: atmospheric and volcanologic implications. Geology 5, 621-624.

Sarmiento, J.L., 1993. Atmospheric $\mathrm{CO}_{2}$ stalled. Nature 365, 697-698.

Suárez-Morales, E., Gasca, R., 1998. Thecosome pteropod (Gastropoda) assemblages of the Mexican Caribbean Sea (1991). The Nautilus 112, 43-51.

Sunda, W., 1988-1989. Trace metal interactions with marine phytoplankton. Biological Oceanography 6, 411-442.

Trofimovs, J., Amy, L, Boudon, G. Deplus, C. Doyle, E., Fournier, N., Hart, M.B., Komorowski, J.C., Le Friant, A., Lock, E.J., Pudsey, C., Ryan, G., Sparks, R.S.J., Talling, P.J., 2006. Submarine pyroclastic deposits formed at the Soufriere Hills volcano, Montserrat (1995-2003): what happens when pyroclastic flows enter the ocean? Geology 34, 549-552.

Watson, A., 1997. Volcanic $\mathrm{Fe}, \mathrm{CO}_{2}$, ocean productivity and climate. Nature 385 , 587-588.

Wells, F.E., 1975. Comparison of Euthecosomatous pteropods in the plankton and sediments off Barbados, West Indies. Proceedings of the Malacological Society London 41, 503-509.

Wells, F.E., 1976. Seasonal patterns of abundance and reproduction of Euthecosomatous pteropods off Barbados, West Indies. The Veliger 18, 241-248. 